\title{
GLOSA Y PARODIA DE LOS SALMOS PENITENCIALES EN LA POESÍA DEL CANCIONERO
}

\author{
VALENTIN NÚṄEZ RIVERA \\ Universidad de Huelva
}

«...que al buen mártir de amor con la pasión de las muchas muertes se le dobla la fe...»

Juan de Flores

\section{RESUMEN}

Los Salmos penitenciales constituyeron la pauta para la creación de una serie de poemas religiosos durante el siglo XV. En este artículo se estudian ess versiones "en seso", como, por ejemplo, las composiciones de Guillén de Segovia, Luzón y Juan del Encina. Pero, además, los salmos fueron también objeto de una lectura paródica de contenido amoroso. Poemas de este segundo tipo son los salmos contrahechos de Valera, Villalpando, Gaçull y el propio Encina.

A partir de 1559 muchas fueron las cortapisas inquisitoriales para que pudieran circular libremente las recreaciones poéticas de los Salmos, uno de los veneros fundamentales de la influencia bíblica en nuestra literatura del Siglo de Oro. Ese panorama cercenador, que se evidencia aún más si cabe en las traslaciones en prosa, lo explicó Alberto Blecua en un trabajo memorable. Pocas son las traducciones métricas de los Salmos en torno a las fechas referidas. En todo caso, la producción se restringe a los circuitos de la difusión manuscrita. Tal es lo que ocurre, por ejemplo, con los salmos de fray Luis de León, el autor da- 
vídico más importante en todo el periplo. Habrá que esperar a tiempos mejores para que los salmos poéticos se plasmen sin excesivo problema en las colecciones impresas, algo que ocurre de nuevo en el Cancionero de la doctrina cristiana de 1579, compilado por López de Úbeda '.

Frente a esta dificultad postridentina, el eco de los Salmos de David conoció un reflejo más fluido en la poesía del siglo XV. Sin ir más lejos, en el Cancionero General encontramos Los siete Salmos penitenciales glosados por Guillén de Segovia y el De profundis de Mosén Gaçull. Bien es verdad que su respectiva conformación y propósitos son francamente dispares, pero ambas composiciones prueban la cierta atención que la lírica de cancionero prestó a los libros poéticos de la Biblia ${ }^{2}$. Esa dedicación, no es, desde luego, sino una tímida y colateral faceta del inmenso corpus cancioneril. En especial, si lo comparamos con la extensa producción áurea. Con todo, la opinión de Márquez Villanueva a propósito de esta influencia es más radical. Entiende que «la Biblia proporcionó a los poetas de cancioneros, de temas, de modalidades expresivas y estilísticas; el influjo bíblico puede alinearse con toda seguridad, junto a los más importantes que se ejercitaron sobre la poesía del siglo XV" ${ }^{3}$. Por eso, estima desacertada la idea de Pierre Le Gentil ${ }^{4}$ cuando llega a afirmar que «el descubrimiento de la Biblia no se había realizado aún a finales del siglo XV» ${ }^{5}$. Sólo disculparía la aseveración del crítico francés, siguiendo de nuevo a Márquez Villanueva, el entendimiento de dicha influencia como una recuperación arqueológica de los textos sagrados ${ }^{6}$. Algo para lo que habrá que esperar, en efecto, al Siglo de Oro, donde se entiende un sistema poético bíblico, conformado por los Salmos y el Cantar de los Cantares, en paralelo al esquema clasicista de odas y

' Para estas cuestiones relativas a la poética de los Salmos en el Siglo de Oro, véase ALBFiR [O) BLECUA, «El entorno poético de fray Luis», en Academia Literaria Renacentista. I. Fray Luis de Le'on, Salamanca, Universidad, 1981, pp. 77-99 y J. VALENTf́n NúN̄Ez RIVERA, «La versión poética de los Salmos en el Siglo de Oro: vinculaciones con la oda», en La oda, ed. Begoña López. Bueno, Scvilla, Universidad, pp. 335-382.

2 Lo ha destacado Alan Deyermond, «Unas alusiones al Antiguo Testamento en la poesía de cancionero", en Homenaje a Antonio Vilanova, ed. A. Sotelo, Barcelona, Universidad, I989. II. pp. 189-201. Existe un libro de conjunto sobre el tema: Celso BAÑEZA ROMÁN, Influcncia de la Biblia en la literatura medieval española, Las Palmas, 1996.

${ }^{3}$ Francisco Márquez VIllanueva. Investigaciones sobre Juan Álvarez Gaus. Contrihuririn al conocimiento de la literatura castellana del siglo XV. Madrid, RAE, 1974, 2." ed., dedica las pp. 167-176 a la familiaridad del autor con las Sagradas Escrituras. La cita se toma de la p. 175.

4 Pierre Le GeNTIL, La poésie lyrique espagnole et porrugaise a la fin du Moyèn Á.ge. I-II. Les thèmes. les genres et les formes (1949-1953), Paris. Slatkine. 1981.

s apud Márquez Villanueva, ob. cit., p. 176.

' Márquez Villanueva, ob. cit., p. 156. 
églogas ?. Una implicación que, sin embargo, conoce una remota ascendencia, puesto que arranca de los judíos alejandrinos (Flavio Josefo, Filón de Alejandría), y llega a los Santos Padres, especialmente a san Jerónimo o san Agustín ${ }^{8}$. Precisamente, de entre los libros poéticos de la Biblia, sobresale en el cancionero la versión de los Salmos penitenciales ${ }^{9}$. También encontramos alguna recreación del Job y Jeremías, aunque contrahechos a lo profano, como luego diremos, y ciertos atisbos del Cantar de los Cantares ${ }^{10}$. Pues bien, a pesar de todo, este corpus reducido de poesía bíblica conoció bien pronto la censura inquisitorial. Porque los salmos de Guillén de Segovia, por ejemplo, no se reimprimieron en las ediciones sucesivas del Cancionero. Y también tuvo problemas de censura otro texto bíblico, las Liçiones de Sánchez de Badajoz ${ }^{11}$. En este segundo caso las razones parecen ser evidentes, puesto que se trata de una parodia amorosa del texto bíblico. Pero el primer poema es una versión absolutamente ortodoxa, lo cual demuestra la sospecha inevitablemente anexionada a cualquier texto romance sobre las Sagradas Escrituras. El caso es que la familiaridad con la Biblia en el siglo XV era muy intensa, entre otras razones, por la persistente traducción del texto bíblico, a manos muchas veces de judaizantes.

No me puedo detener ahora en un hecho trascendental para el desarrollo de la prosa del Medioevo, pero recordaré, al menos, cómo el apogeo de las Biblias romanceadas, al principio a partir de la versión Vulgata, se produce en el trecho que va de Fernando III a Alfonso X. Un período que coincide con las prohibiciones de la Escritura en vernáculo dictaminadas en los concilios de

7 De ello he tratado en mi art. cit. sobre los Salmos. Para el Cantar de los Cantares téngase en cuenta, mi Arias Montano y el "Cantar de los Cantares». Estudio y edición de la «Paráfrasis en modo pastoril». Kassel, Reichenberger. 2001. en colaboración con Luis Gómez Canseco. Véase, asimismo, mi «De égloga a lo divino y bucólica sacra. A propósito del Cantar de los Cantares en la poesía áurea», en Lá égloga. ed. Begoña López Bueno, Sevilla, Universidad de Sevilla, 2002, 195-251.

* Cfr. María Rosa Lida DE Malkiel, «La métrica de la Biblia. Un motivo de Josefo y san Jerónimo en la literatura española», en Estudios hispánicos homenaje a Archer M. Huntington. Wellesley. Wellesley College, 1952, pp. 335-359. Además, vid. Luis Gómez Canseco y M. A. Márquez, eds., BENITO ARIAS MONTANO. Tractatus de figuris rhetoricis cum exemplis ex Sacra Scriptura petitis, Huelva. Ediciones Clásicas/Universidad de Huelva, 1995, pp. 9-33.

"Se trata de los salmos de la Vulgata: 6, 31, 37, 50, 101, 129, 142.

10 Conozco dos trabajos sobre esta última influencia: TONY HUNT, «The Song of Songs and Courtly Literature" en Court and Poet: Selected Procedings of the Third Congress of the International Courlty Literature Society, ed. Glyn S. Burgess, Liverpool, Francis Cairns, 1981, pp. 189196; Peter Dronke, «The Song of Songs and Medieval love-lyric» (1979), en The Medieval Poets analisis World, Roma, Edizioni di Storie e Lettere, 1984, pp. 109-236.

"Para los datos sobre este poeta me baso en la monografía de PATrick Gallagher, The $\mathrm{Li}_{\text {- }}$ fe and Works of Garci Sánchez de Badajoz, Londres, Támesis, 1968. 
Toulouse (1229) y Tarragona (1233-1234) ${ }^{12}$. En este contexto se emplaza, al igual, la versión probablemente más antigua de los Salmos en castellano, el Salterio de Hermann el Alemán (1268-1272) ${ }^{13}$. Más cercana a nuestro ámbito se encuentra la Biblia de Alba (1422-1433) y, rebasando el límite cronológico, la Biblia de Ferrara, publicada en el XVI, pero dependiente de una base cuatrocentista ${ }^{14}$. En ambos casos, como en la versión del Salterio, la fuente bíblica la constituye el texto hebreo. Todos esos romanceamientos tienen lugar entre constantes prohibiciones inquisitoriales ${ }^{15}$. Poseemos datos precisos de persecuciones en 1490,1492 y $1497^{16}$. Y lo más llamativo es que muchas de esas traducciones, ya lo he referido, parten del texto hebreo, lo cual supone una problema teológico aún mayor. Y es que el Salterio, concretamente, fue uno de los libros más apreciados de la tradición hebraica.

Por añadidura, estos recelos provendrían del prejuicio antijudaico con que iba teñido todo lo relacionado con el Antiguo Testamento. Es cierto que el libro de los Salmos era uno de los preferidos para los conversos y que debieron circular muchas copias manuscritas del Salterio. Conservamos el testimonio de Rodrigo Alfonso, un converso de Guadalupe procesado en 1485, sobre la lectura que hacía regularmente de los versos de David en casa de sus sobrinas ${ }^{17}$. En relación a este aprecio converso por los Salmos, Marcel Bataillon se preguntó si la melancolía subyacente en la paráfrasis del Super flumina de Montemayor o la vuelta a lo profano del mismo salmo 136, obra de Villegas (ambas de hacia 1550 ), tendrían su origen en un talante judaico ${ }^{18}$. Este salmo, que no encontramos glosado en el siglo XV, aparte de ser uno de los más versionados a todo lo ancho del Siglo de Oro ${ }^{19}$, significó en muchas ocasiones la expresión más evi-

12 La bibliografía sobre el tema es extensísima, sobre todo gracias a los trabajos de Margherita Morreale, por lo que sólo citaré el actualísimo estado de la cuestión de ÁNGEL. GoMEZ REDONDo, «Judíos y conversos en la prosa castellana medieval (con un excurso sobre el círculo cultural de marqués de Santillana», en Judíos en la literatura española, coord. Iacob M. Hassán y Ricardo Izquierdo Benito, Cuenca, Universidad de Castilla-La Mancha, 2001, pp. 57-86.

13 Vid. María Wenceslada de Diego Lobejón, El salterio de Hermann el Alemán (Ms. Es curialense $(-j-8)$, Valladolid, Universidad, 1993.

14 Cfr. GOMEZ Redondo, art. cit., pp. 63-64.

15 Téngase en cuenta Jesús ENCISO, «Prohibiciones españolas de las versiones bíblicas en romance antes del Tridentino», Estudios biblicos, 3 (1944), pp. 532-560.

16 Lo refiere Márquez Villanueva, ob cit., p. 174.

17 Cfr. Nicolás LOPEZ MARTínez, Los judaizantes castellanos y la Inquisición en tiempos de Isabel la Catolica, Burgos, Imprenta Aldecoa, 1954, p. 136.

18 Marcel Bataillon, «Melancolía judía o melancolía renacentista», en Varia lección de clásicos españoles, Madrid, Gredos, 1964, pp. 39-54.

19 José ManUel BlecuA, "Sobre el salmo Super Flumina», en Homenaje a Eugenio Asensio, Madrid, Gredos, 1988, pp. 113-126. 
dente del autoexilio hebreo, de ese "vivir amargo", del que nos habló Américo Castro. El maestro francés brinda, por tanto, la hipótesis de una «excepcional saturación jeremíaca» para explicar varias facetas de la literatura desde finales del $X V$ a la mitad del XVI ${ }^{20}$. No podemos olvidar, abundando en este razonamiento, que Guillén de Segovia y Diego de Varela, dos de nuestros autores más destacados, contaban con más que probables orígenes conversos ${ }^{21}$. También se han intuido ascendentes judaicos para Juan del Encina ${ }^{22}$. Asimismo, se debe notar que María Rosa Lida llegó a entender el auge de la hipérbole sagrada durante el $\mathrm{XV}$ como un fenómeno íntimamente relacionado con el tema converso ${ }^{23}$. Y no digamos, la amplia vertiente de la poesía satírica, plagada de autores no limpios ${ }^{24}$. Tanto en el caso de la insistencia bíblica como en el gusto por la sátira inconformista habría que destacar ese espíritu de insumisión a las convenciones que don Américo diagnosticó como rasgo literario de la casta perseguida ${ }^{25}$.

De todos modos, la irreverencia frente a los modelos no será la tónica exclusiva. Bien es cierto que resulta abundante, pero también contamos con recreaciones absolutamente rectas sobre el libro de David. Así pues, para el estudio de los Salmos en la poesía de cancionero se debe tener en cuenta desde el principio una distinción entre dos tipos de acercamiento al texto bíblico. Un grupo de composiciones recrea, con mayor o menor literalidad, las palabras de la Vulgata; no hay sentidos ocultos, ni códigos subyacentes. Es, por tanto, poesía religiosa y, más concretamente, de modalidad penitencial. El otro conjunto, sin embargo, se cuenta entre las numerosas parodias de los textos sagrados a lo largo del siglo $\mathrm{XV}$. Nos las habemos, pues, con dos mecanismos poéticos diversos, pero que, por proceder del mismo marco de referencias e imágenes, se compenetran en muchas de sus características. La versión literal y las variaciones en clave erótica, constituyen, por tanto, las dos caras de un mismo fenómeno de recreación del

20 Bataillon, ob. cit., p. 50.

21 Cfr. Pedro Guillén de Segovia, Obra poética, ed. Carlos Moreno Hernández, Madrid, FUE. 1989, pp. 32-65 y para Valera, Nicasio SAlVADOR Miguel, La poesía cancioneril. El «Cancionero de Stúniga», Madrid, Alhambra, 1977, pp. 242-254.

22 Especialmente, Francisco Márquez Villanueva, «La Trivagia y el problema de la conciencia religiosa de Juan del Encina», La Torre, Nueva Época. 1 (1987), pp. 473-500.

23 Vid. su clásico estudio «La hipérbole sagrada en la poesía castellana del siglo XV» en Estudios sobre la literatura española del siglo XV, Madrid, José Porrúa, 1977, pp. 291-309. Un parecer opuesto manifiesta Michael Gerli, Poesía cancioneril castellana, Madrid, Akal, 1994, p. 58, que recoge otras opiniones en este sentido.

24 Por ejemplo, vid. el propio Márquez Villanueva, ob. cit., Julio Rodríguez Puértolas, Poesía crítica y satírica del siglo XV, Madrid, Castalia, 1989 o KenNeTh SHOLberg, Sátira e invectiva en la España medieval, Madrid, Gredos, 1971.

25 Téngase en cuenta la revisión de EugENIO ASENSIO, «La peculiaridad literaria de los conversos», en La España imaginada de Américo Castro, Barcelona, Crítica, 1992, pp. 87-119. 
texto bíblico, que llegan a compartir incluso el mismo espacio manuscrito o impreso. Y no es sólo cuestión de un idéntico medio de cauce material. La prueba palmaria de esta coexistencia acontece en la obra poética de un autor tan proteico como Juan del Encina, que combina la versión en seso del Miserere con la traslación paródica de varios Salmos del oficio de difuntos.

\section{SALMOS DE AMOR DIVINO}

Si la faceta davídica en la poesía de cancionero ha sido escasamente valorada, ello es el síntoma de una carencia de más amplio alcance. Poco se ha atendido en su conjunto a la poesía religiosa del siglo $\mathrm{XV}{ }^{26}$. Bien es cierto que últimamente han ido apareciendo algunas aproximaciones al fenómeno de la religio amoris en sus varias ramificaciones ${ }^{27}$. Pero ha solido explicarse el aspecto paródico de los Salmos como uno más de los enclaves religiosos que conocen la implantación de una lectura erótica. Por tanto, se ha obviado por lo común la posible relación existente entre las versiones religiosas, más o menos literales, y esas otras contrahechas, una doble aproximación al código bíblico que me parece de máxima importancia para comprender el fenómeno en toda su magnitud. Porque muchos de los rasgos en serio prefiguran algunas de las trazas de las versiones paródicas.

En este sentido, el contexto donde se emplazan las traducciones del Salterio participa de una serie de particularidades que deben ser, como mínimo, esbozadas. En general, durante todo el siglo se prolonga la tradición hagiográfica y mariana del período precedente, una tendencia que, en realidad, no mengua casi en ningún momento. La razón está en que el canto a los principales mediadores entre Cristo y el cristiano conforman el fundamento de la práctica devota. Sólo hay que echar un vistazo a la primera sección del Cancionero general para espigar un nutrido corpus de loores, gozos y dolores de la Virgen, junto a poemas en alabanza a los más diversos Santos. Pero en el último cuarto de la centuria comienzan a proliferar poemas de más amplio aliento sobre hechos particularmente destacados en la vida de Cristo. Esta atención significativa hacia Cristo, en el centro de toda la vida espiritual, es el resultado más evidente de la aclimatación castellana de la Devotio moderna ${ }^{28}$. Una espiritualidad renovada que desarrolla la ejemplaridad

26 Cfr., como excepción. Michel Darbord, La poésie religieuse espagnole des Rois Catholiques à Philippe II. Paris, Centre de Recherches de l'Institut d'Études Hispaniques, 1965.

27 Fundamentalmente, FrANCISCO CROSAS, «La religio amoris en la literatura medieval» en La fermosa cohertura. Lecciones de literatura medieval, Pamplona, EUNSA, 2000, pp. 101-128.

2x Para la caracterización de este movimiento véase el clásico estudio de AlBERT HyMA. The Christian Renaissance. A History of the Devotio Moderna, 2." ed., Aechon Books, Hamden, Conneticut, 1965. 
modélica de la vida de Jesús. La plasmación poética de la nueva piedad se configura en obras que rinden sobre todo tributo al ciclo pasional, sin olvidar otros momentos del Evangelio. Así, contamos con la Pasión trovada de Diego de San Pedro, las Coplas de la Pasión con la Resurrección del Comendador Román, la Vita Christi fecha por Coplas de fray Íñigo de Mendoza, las Coplas de Ambrosio Montesino o el Retablo de la vida de Cristo de Juan de Padilla ${ }^{29}$.

Todos estos poemas ponen gran énfasis en la humanidad de Jesús, lo que conlleva, por lo demás, la valoración de los aspectos más intimistas y emotivos de la práctica religiosa. Los fundamentos de esta enseñanza arraigan tras las ideas de San Bernardo, trasmitidas más tarde por las Meditaciones del pseudo Buenaventura con una amplitud pasmosa. En España se editan nada menos que cuatro veces entre 1493 y 1499 . La técnica de meditación recomendada parte de la lectura de las Sagradas Escrituras, que son las únicas, a través del principio rector de la vida de Cristo, que pueden ayudar a los lectores a alcanzar la comprensión devota. Esa comunicación con Dios a través de la Biblia es la lección de interioridad que proporciona la Imitatio Christi de Tomás de Kempis, libro de cabecera para todo el período ${ }^{30}$.

Como una vertiente importantísima de esta tendencia intimista debe entenderse la relevancia del diálogo del cristiano con la divinidad, es decir, la oración y arrepentimiento sincero y directo por los pecados cometidos. Lamento por la vida pecaminosa que acontece por antonomasia en el conjunto de los Salmos penitenciales. Frente a los Evangelios, centrados en la vida de Cristo, el Antiguo Testamento proporciona un modelo de pecador arrepentido y suplicante que reclama en sus plegarias los actos de la justicia divina. Ello ocurre de modo máximo en el canon de los Salmos penitenciales, constituido desde el siglo IV, donde el salmista implora el perdón de sus faltas ${ }^{31}$. El Salterio en su conjunto, y muy especialmente esos siete Salmos, constituye el primer devocionario para el cristiano, el devocionario revelado. Teresa de Cartagena, por ejemplo, una de las voces femeninas más interesantes de la literatura del XV, con una inevitable ascendencia conversa, considera que los Salmos son el «devotísimo cancionero» de David ${ }^{32}$. Con esta idea no hace más que actualizar el

29 Puede verse, Francisco López Estrada, Introducción a la Literatura medieval española, Madrid, Gredos, 1987, pp. 208-232. También, la introducción a Diego dE SAN PEDRo, Obras completas, III. Poesía, ed. Torothy S. Severin y Keith Whinnom, Madrid, Castalia, 1979. Además, váyase a KEITH WHINNOM, «The supposed sources of inspi os spanish century religious verse», Symposium, XVII ( 1963), pp 268-29I.

30 Diego de San Pedro, ed. cit., p. 16.

"Para la caracterización de los géneros de los Salmos, acúdase al clásico estudio de H. GuNKEL, Introducción a los Salmos, Valencia, EDICEP, 1983. Téngase en cuenta también, LuIS ALONso Schókel y Cecilia CaRniti, Salmos 1. Estella, Editorial Verbo Divino, 1992.

32 Apud Márquez Villanueva, ob. cit. p. 176. 
tópico de las porciones líricas en la Biblia, recibido desde Josefo y san Jerónimo. De forma muy semejante lo recogieron dos escritores coétaneos. Pero Díaz de Toledo en la introducción a la Exclamaçión e querella de la gouernaçión de Gómez Manrique dice sobre los Salmos que: «Dauid assy mesmo todo su Salterio escriuió en metro, e segund dize sant Gerónimo, usó de diversas leyes reglas de metros», extremo que igualmente repite Santillana en la Carta-Prohemio: "Dauid cantó en metro... todos los cinco libros del Salterio" ${ }^{33}$.

En cuanto al corpus de las versiones en seso, contamos, concretamente, con una glosa completa por parte de Guillén de Segovia, con sendos poemas, uno de Encina y otro de Luzón, sobre el Miserere, el salmo más traducido del Salterio ${ }^{34}, y$, por último, con una refundición dialogada sobre el De profundis, también de Luzón. Esto por lo que se refiere a poemas que recrean por entero uno o varios salmos, porque las citas, ecos o alusiones desperdigadas al Salterio son también bastante abundantes.

La perspectiva de espiritualidad recogida e íntima a la que me vengo refiriendo se muestra muy a las claras en los Salmos penitenciales de Guillén de Segovia ${ }^{35}$. Su poema consiste ante todo en una versión bastante ceñida de los siete Salmos bíblicos, aunque la aparición de dos piezas prologales añadidas y el remate, un colofón también de creación propia, rodean la figura estereotipada del salmista con una voz más personal. Dicho de otro modo: ese paratexto permite identificar el enunciado del poema con la enunciación del poeta, olvidándonos por momentos de la mediación bíblica. La lectura de la obra desde esta perspectiva nos ayuda a diseñar la entidad de un pecador arrepentido, enfermo y dolorido por los pecados que cometió. Desde el punto de vista de su trayectoria vital se encuentra en el «arrabal de senectud», desde donde contempla los yerros a lo largo de la juventud pasada. Una suerte de palinodia que resulta igualmente común en la poetización del itinerario amoroso de los poetas contemporáneos, como Padrón, Villasandino, Álvarez Gato, Mena, Santillana o Manrique, y que aparece asimismo, por influjo de Petrarca, en los poetas del Siglo de Oro ${ }^{36}$. Por tanto, nos las habemos con un pecador rodeado y atenazado continuamente por enemigos y contrarios que lo acosan y lo tientan a cometer «perversas iniquidades». En estas

33 Apud LIDA DE MALKIEl, "La métrica de la Biblia..., pp. 343-344.

34 Para un amplio repertorio de las versiones sobre el Salterio, véase MARia WENCESLADA DE Diego LoBejón, Los Salmos en la literatura española, Valladolid, Universidad, 1996.

35 Ed. cit., pp. 259-284.

${ }^{36}$ Cfr. OTIS H. GREEN, «El pródigo y su vuelta», en España y la tradición occidental, Madrid, Gredos, 1969, I, pp. 306-345. Además, vid. FRANCisco Rico, «Prólogos al Canzoniere (Rerum Vulgarium Fragmenta I-III)», Annali della Scuola Normale Superiore di Pisa, III, XVIII, 3 (1988), pp. 1071-1104. 
condiciones desfavorables el salmista se dirige humilde al «Santo padre», con la súplica de un perdón reconfortante, que se patentiza en términos como salud o sanidad, en correspondencia con la metáfora de su propia dolencia. Si la imagen del pecador adquiere los visos de un enfermo a causa del pecado, la figura de Dios se nos muestra como juez implacable, pero justo, de la conducta humana.

El primer prefacio, que falta en el Cancionero General, es un «prólogo en prosa fingiendo que fabla con su amigo». Ello no es una característica exclusiva para esta obra de Guillén, ya que el poeta prologa de modo parecido gran parte de sus poemas de mayor alcance, y generalmente de carácter suplicatorio $^{37}$. En esa dedicatoria fingida revela el «movedor fin" que le ha conducido a romper el silencio «a la pluma temerosa». Según le explica al destinatario, la referencia del azoramiento íntimo se produce a causa de dos motivos. La primera razón insiste en el carácter penitencial del acto poético, su confesión abierta de los pecados cometidos y la petición de perdón:

E como a mí poseedor suyo vigurosa por antigüedad sojuzgase ocultos delitos del ánima perdiçión cometer me fizo. E yo temorizado de los que dixe ocultos venir en tanto publicos que disfama o quiça vil muerte en agena tierra me causasen considere mitigar la furor suya $y$ ante las sus fuerças poner pertrechos de onestos exerçiçios en defension mia lo qual platicando por mi breve juizio e con el vaçilando en distintas quistiones acordo mi querer seguir ${ }^{38}$.

En la segunda explicación, a más de consignar los consabidos tópicos de modestia, le refiere al amigo cómo el acto poético ha sido el fruto de una revelación. Una suave voz angelical le ha inspirado el aliento lírico «en servizio e alabança de nuestro causador». Pero hoy no nos es muy clara la fecha de tal arrebato y, por consiguiente, de la composición. Aunque acaso pudiera datarse hacia 1474 por ciertos datos del prólogo ${ }^{39}$. Tras el prefacio en prosa, «Síguese otro prólogo en metro», que podría considerarse como un salmo personal, es decir, una recreación libre de la mayor parte de los elementos recurrentes en la colección de poemas bíblicos. Así pues, y siguiendo las marcas definitorias que ya he recalcado, su canto son «gemidos / e rogarias / de lagrimas e plegarias / bastecidos» (vv. 1-4) ${ }^{40}$, y el propósito de la súplica consiste en la llamada de

${ }^{37}$ Véase, ed. cit, $n{ }^{\circ} 10,11,26,27,28,29$. Como complemento a esta edición, véase del mismo autor, Carlos Moreno Henández, «Algunas enmiendas a una edición de Pedro Guillén de Segovia", Cuadernos para la Investigación de la Literatura Hispánica. 12 (1990), pp. 99-104.

38 Ed. cit., p. 259.

39 Cfr. ed. cit., pp. 82-83.

4) Desde ahora indico el número de versos de la composición (ed. cit., pp. 260-284). 
la atención del Señor: «enclina las tus orejas / a mi clamor» (15-16), le dice. En esta introducción, como no podía ser de otro modo, se dirige concretamente a Jesucristo. Ello es evidente si reparamos en los versos siguientes:

Tu nos diste ley bendita

de la cruz

Tu eres luz de la luz

infinita

Tu que das la ques escrita

Salvaçion... (25-30)

La figura de Cristo, en cuanto camino fundamental de salvación, queda patente en otros versos, como «... e me rijo / por tu vida», "tus santas obras / ilustrantes» (51-52), «...de tus fechos como son /admirantes» (55-56). Téngase presente, a pesar de esto, que originariamente los Salmos iban destinados a Dios padre, a Yahveh, por lo que este prólogo deja notar de forma muy clara el proceso de adaptación del texto bíblico a las coordenadas espirituales del tiempo. En general, Guillén de Segovia es muy respetuoso con el designio bíblico, pero en algún momento de la traslación afloran referencias palpables al ámbito cristológico y cristiano. Dos ejemplos muy elocuentes se encuentran en el salmo V. Dice allí, «Olvidé comer el pan / de penitençia» (607-608); y más tarde, «e la tu santa ygleja temerán» (679-680). Pero, como digo, estos resabios son aislados a lo largo de la versión, que, por lo común, se mantiene en las coordenadas escriturísticas. En cualquier caso, el poeta no hace más que poner en práctica la visión tipológica medieval, el método más frecuente para armonizar los acontecimientos de la era cristiana con los hechos del Antiguo Testamento ${ }^{41}$.

Ese marco de contextualización del texto bíblico, tan concienzudamente diseñado, se cierra mediante cuatro estrofas en «Suplicaçión a los sabios», donde Guillén pide de nuevo la benevolencia para con su «tratado». Y lo hace dirigiéndose a los «doctores / maestros e sabidores / en teologia». Les solicita finalmente: «Que por ellos diçernido / mi tratado / si yerro le sera dado / conoçido / que no sea atribuydo / a voluntad / mas a mengua e çeguedad / del sentido» (921-928).

A partir del prólogo poético, que termina con un ofrecimiento relativo a la serie de los siete salmos siguientes («Te quiero por careçer / fuegos mortales / los salmos penitençiales / ofreçer», 85-88), ya podemos identificar las marcas métricas y estructurales del poema. En el aspecto métrico, la estrofa utilizada

"Cfr., por ejemplo, Alan Deyermond, «La Biblia como elemento unificador y divisorio en la literatura medieval de Castilla», en La religión como factor de integración y conflicto en el Mediterráneo, Madrid, Ediciones Clásicas, 1996, pp. 127-156, pp. 130-132. 
(8a-4b-8b-4a-8a-4c-8c-4a), es un tipo de sextilla de pie quebrado, distinta de la manriqueña, que coincide con la que eligió Santillana para sus Proverbios. Ello muestra su perfecta adecuación para la poesía didáctica y moral. También resulta un esquema muy a propósito a la hora de verter los cantos fúnebres, como manifestó Alonso Getino, al reseñar los antecedentes más inmediatos de esa práctica tan común durante el XV, en autores como Aguayo, Encina, Rodríguez del Padrón, etc. ${ }^{42}$.

Con relación a la arquitectura global es preciso subrayar que el número siete entraña una marcada significación simbólica, por analogía con otros conjuntos de elementos religiosos, como los pecados capitales o las virtudes teologales, las palabras de Cristo, los gozos y angustias de María, sobre los cuales se confeccionaron poemas tanto en serio como en clave amorosa ${ }^{43}$. La presencia de un patrón tan férreo adquiere además una función constructiva, puesto que sostiene y orienta el recorrido poético, dotando de equilibrio a las unidades menores, que no se ven predispuestas a desproporciones o digresiones inconexas ${ }^{44}$. No obstante, por lo que respecta a la proporción estructural de cada parte en el conjunto, la irregularidad resulta extrema, pues los salmos fluctúan entre las 5 estrofas del VI, a las 24 del V, no existiendo ninguna cantidad de versos que se repita.

Esta variabilidad, que indudablemente conduce a un cierto desequilibrio constructivo, obedece a una razón muy obvia. Dado que la traslación de los Salmos es tan ceñida al modelo, la amplitud de cada uno de los segmentos depende muy estrechamente del número de versículos del original ${ }^{45}$. No existen, así pues, amplificaciones o reducciones llamativas, sino que la correspondencia se mantiene en todo el decurso poético. Lo que sí obedece a una proporcionalidad casi matemática es la dedicación unívoca de una estrofa para cada uno de los versículos de la Vulgata, un hecho que demuestra el seguimiento cuidadoso de los versos latinos y la regularidad en la dosificación de los términos romances. Con todo, se pueden distinguir algunas excepciones a este principio. En el salmo segundo, por ejemplo, apreciamos una modificación sobre el diseño de las intervenciones del pecador y de Yahveh, que también toma la palabra. Al Señor corresponderían los versículos 8 y 9 . Pero Guillén adjudica el octavo al salmista y el 9 (Nec conclusisti me in manibus inimicis;

\footnotetext{
Anales valmamimos, II, Salamanca, 1929, pp. 176-219, concretamente pp. 176-177.

"Per ciemplo. Ios sirece pecades de Mena y Manrique. las Siete angustias de Manrique. Cfr. Sin Ploker.ed cit. p. 38 .

"Siv Plotoks. ed. cit. p. 50.

1. Silmo I (6). 9 estrofas: 2 (31), 16 estrofas: 3 (37), 17 estrofas; 4 (50), 19 estrofas; 5 (101). 24 esirutie: $6(129), 5$ estrotas; 7 (142), 12 estrofas.
} 
Statuistis in loco spatioso pedes meos) lo parafrasea en dos estrofas, plenas de circunloquios: «No querays ser comparados / en visajes / a los muy fieros salvajes / denodados / quen las selvas son criados e sin tiento / de ningún entendimiento /son fallados / con cabestro pues conviene / e ayuno / quebrantad al importuno / que mantiene / maliçia y la sostiene / insuave / penitençia aya grave / porque pene» (257-272).

Como señalaba hace un momento, a lo largo de toda la glosa el Dios que aparece es el padre justiciero, que produce «espanto» (454). Sus dos características más implacables son la «ira» y la «saña», términos con los que recoge Guillén los latinos ira y furore. A veces, no obstante, le llama «mesurado» (497). En realidad, el poeta está aplicando parámetros típicamente medievales en esta caracterización. No hay más que comparar con algunos de los rasgos que definen a Alfonso VI en el Cantar de Mio Cid o andando el tiempo, la actitud del padre de Laureola en Cárcel de amor de Diego de San Pedro. La tendencia a que obedecen tales especificaciones no es más que un indicio del afán de verosimilitud. Unos rasgos verosimiladores que quizá se aprecien también cuando el poeta añade como amplificación de 6,3: «mis huesos atormentados / e mi alma / ser no pueden sin tu palma / reparados» (101-104), imagen que recuerda la iconografía del señor feudal, dispensador de justicia a sus deudos vasalláticos ${ }^{46}$. Igualmente, puede ser interesante para aquilatar esta actualización de los contenidos que el autor se refiera al pecado en general como «codicia», que es la fuente de todos los pecados capitales $(785,822)$, lugar común identificable a lo largo de la clerecía medieval ${ }^{47}$. Asimismo, la paráfrasis participa a veces de una mentalidad típicamente cuatrocentista. Obsérvense, si no, los versos, «Todos quantos naçeran / y son naçidos / con serviçios elegidos / te servirán / desde el pobre con afán / fasta el rey / tus mandamientos e ley / guardarán» (721-728), donde se pone de manifiesto la equiparación de cada uno de los «estados» frente al poder igualador del Dios padre, de modo muy semejante a como ocurre en las Danzas de la muerte.

Con atención al vocabulario religioso, que más tarde se empleará con un sentido erótico, resulta interesante la versión que hace Guillén de 50, 10, por ejemplo: «y mis huesos omillados / en plazer» (487-88), donde recoge la idea bíblica mediante una paradoja típicamente cancioneril; asimismo, la profusión del verbo «servir», término clave en la concepción del amor cortés, o la aparición de las «saetas» en el salmo 37, 2 («ca ya sabes conçebi / tus saetas / quen

46 De nuevo, el Poema de Mio Cid o Cárcel de amor, podrían ser ejemplos perfectos.

47 Así se muestra en el Libro de buen amor, por ejemplo; «De todos los pecados es raíz la codicia» (218a), siguiendo a San Pablo, I ad Tim., VI, 10. 
mi coraçon secretas / reçebi», 301-304), que en las versiones profanas se identificarán con las armas del dios Cupido. En general, abundan los circunloquios o expresiones que intentan verter con bastante aproximación el término latino. Esta tendencia a la proliferación de cultismos y resabios latinizantes es una característica de las versiones bíblicas a medida que transcurre el siglo XV. Los romanceamientos del siglo XIII, sin embargo, intentaban por todos los medios acercar la fuente bíblica a la lengua común. Un distanciamiento que vendría explicado como consecuencia de las sucesivas prohibiciones inquisitoriales, que fueron asemejando las versiones al respectivo modelo latino ${ }^{48}$.

Más tardía que los salmos de Guillén de Segovia debe de ser la versión del Misere que Juan del Encina incluyó en su Cancionero de 1492, en el contexto de las numerosas paráfrasis sobre diversos himnos litúrgicos, el Padre Nuestro $y$ otras oraciones ${ }^{49}$. Este autor entraña un papel importante como traductor de los dos afluentes que nutren el cauce de la poesía culta del XVI: la Biblia y los clásicos. No hay más que comparar su actitud versionadora con la de fray Luis, también autor de salmos y bucólicas, aunque desde luego, salvando todas las distancias debidas a la muy diversas coordenadas poéticas a que se deben. Encina tradujo, asimismo, las Bucólicas de Virgilio, un texto que supone en muchos sentidos la incardinación por primera vez de la poesía española en el ámbito del humanismo poético ${ }^{50}$. Pero la versión del salmo 51 resulta mucho más apegada al original bíblico que la alegórica traslación al modelo virgiliano ${ }^{51}$. El poema consta de 9 coplas castellanas (abbacddc), cada una de cuyas semiestrofas va adjudicada a un versículo de la Vulgata, salvo en el caso de la primera, que ocupa todo el versículo 3. Aquí el tempo se hace más despacioso, quizá porque en esos versos iniciales se consignan gran parte de las ideas luego desarrolladas. Por ejemplo, el primer tramo del versículo (Misere mei secundum magnam misericordiam tuam), queda amplificado de la siguiente for-

48 Vid. MARGhertTa MORREALE, «Estudios lexicograficos sobre las Biblias romanceadas», en Homenaje a Dámaso Alonso, II, Madrid, 1961, pp. 505-536, pp. 527-528.

4 JUAN DEL ENCINA, Obras completas I. Arte de poesía castellana, poemas religiosos y Bucólicas, ed. Ana M. Rambaldo, Madrid, Espasa-Calpe, 1978, pp. 150-195.

${ }^{30}$ Cfr. JEREMY LAWRENCE, «La tradición pastoril antes de 1530: imitación clásica e hibridación romancista en la Traslación de las Bucblicas de Virgilio de Juan del Encina», en Humanismo y literatura en tiempos de Juan del Encina, ed. Javier Guijarro Ceballos, Salamanca, Universidad de Salamanca, 1998, pp. 101-121; y, en general otros varios trabajos del volumen, donde se incluyen artículos sobre la faceta religiosa del autor: ALAN DEYERMOND, «La Biblia en la poesía de Juan del Encina», pp. 55-68; JAVIER SAN JOSÉ LERA, «Juan del Encina y los modelos exegéticos en la poesía religiosa del primer Renacimiento», pp. 183-204.

${ }^{5} \mathrm{Vid}$., por ejemplo, J. C. TEMPRANO, Móviles y metas en la poesía pastoril de Juan del Encina, Oviedo, Universidad, 1975. 
ma: «Duélete, Señor, de mí / según tu misericordia, / pues ay, cierto, sin discordia, / gran misericordia en ti...» (vv. 1-4) ${ }^{52}$.

Aquí podemos apreciar ya una tendencia bastante acusada en toda la paráfrasis que se cifra en la reduplicación de términos y conceptos, haciendo uso muchas veces del juego de palabras y el poliptoton. Veamos varios casos: «Lávame, de aquí adelante, / de mi maldad muy lavado» (9-10), «porque mi maldad malvada» (13), «en verdad, verdad amaste» (25); «buelve tu cara bendita, / quítala de mis pecados, / todos sean perdonados, / todas mis maldades quita" (36-40), etc. Tales rasgos quizás signifiquen que, frente a la versión amplia de Guillén de Segovia, dentro de las consignas poéticas del decir ${ }^{53}$, el poema de Encina se sitúa más cerca de los parámetros de la agudeza, propios de la canción, lo cual se evidencia por el uso de un ritmo muy marcado por la recurrencia y el concepto ${ }^{54}$.

Con los salmos de Juan de Luzón rebasamos en algo el límite temporal del siglo XV, aunque sólo por muy poco espacio, pues, si bien su Cancionero fue publicado en 1508, se concluyó posiblemente en $1506{ }^{55}$. En cualquier caso, la poesía de Luzón entra de lleno en las directrices de la lírica cancioneril, al igual que todos los impresos poéticos salidos de las prensas en esos años iniciales del XVI. Contamos para ese tramo temporal con diversas ediciones de poetas como Mena, Mendoza, Encina, Padilla o Pérez de Guzmán. El libro de Luzón está dividido en dos partes. En la primera, mucho más extensa ( 83 folios), se desarrolla un tratado filosófico-moral sobre las virtudes, en 397 coplas de arte mayor. En la segunda sección van insertas las versiones del Miserere y el De profundis, más una oración sobre el himno $O$ gloriosa domina.

Rodríguez Moñino, editor moderno de la rareza bibliográfica, tildó no sin razón, estas dos versiones como «extrañísima paráfrasis» ${ }^{56}$. El apelativo parafrástico resulta absolutamente adecuado, porque aquí Luzón no se limita a verter los versículos de la Vulgata con razones más o menos apegadas en castellano, sino que amplifica a su antojo, añadiendo toda una serie de elementos absolutamente ajenos al texto davídico. El adjetivo «extrañísima», por su parte, debió emplearlo el insigne bibliógrafo para referirse al pastiche de sentencias la-

52 Ed. cit., pp. 166-168.

53 Para una caracterización de los géneros poéticos cancioneriles, téngase en cuenta, ANA M. Rodado RuIZ, Tristura conmigo va. Fundamentos de amor cortés, Cuenca, Universidad de Castilla-La Mancha, 2000.

54 Sobre esta cuestión resulta imprescindible el libro de JuAn Casas Rigall, Agudeza y retórica en la poesía amorosa de cancionero, Santiago de Compostela, Universidad, 1995.

s5 Sigo la edición facsímil de ANTONIo Rodríguez-Moñino, Madrid, 1959. Se recoge la opinión en p. XI.

s6 Ed. cit., p. X. 
tinas incrustadas en el desarrollo romance. Ello da lugar a una especie de macarronea, anómala en el sistema poético castellano. Pero el procedimiento de Luzón no es siempre el mismo. Centrémonos, primeramente, en la paráfrasis del salmo 51, la más extensa de las dos. El mecanismo de recreación parte de la acomodación de fragmentos de los versículos en una estrofa inicial y, acto seguido, el complemento más libre de un desarrollo sin latines. Pero no encontramos ninguna tendencia asumida como norma o pauta de regularidad. Hay estrofas del primer tipo con una levísima incorporación de palabras bíblicas, como por ejemplo, la estrofa primera, correspondiente al miserere mei, y otras, sin embargo, con una saturación que las convierte en un discurso poético prácticamente bilingüe. Por ejemplo, eso es lo que ocurre en el versículo $8^{57}$ :

Quoniam si te pluguiesse:
sacrificium te haria
sedissem y ahun mataria
por ti la persona mia
que muriendo en ti biviesse
utique mas ciertamente
holocaustis no me do
que no te deleytas no
en que muerte muera yo
ni en querer matar la gente ${ }^{58}$.

Quisiera fijarme ahora en unos cuantos aspectos del poema particularmente interesantes desde el punto de vista temático. Toda la plegaria va dirigida a Cristo. No cabe duda posible de la anacronía, a tenor de versos como: «que in sermonibus dixiste / que a salvar señor veniste / nosotros por quien muriste» (6); o «porque en tu derramamiento» (16). Ello hace que se adoben pasajes del Nuevo Testamento referentes a su vida: «muestrame señor aquel / amor con que respondiste / a la cananea triste importuna / en quien tu viste mayor fe que en Israel» (13); «Quien de Pablo hizo santo / que fue tu perseguidor / también de mi pecador/sin ser yo merecedor / podra hazer otro tanto» (15). Pero lo más llamativo de la versión son una serie de comparaciones bastante chocantes, del tipo de las que estudió Whinnom a propósito de Mendoza, Montesino y Román ${ }^{59}$. El poeta compara, por ejemplo, el pecado cometido con un perro: «et

57 $\mathrm{Y}$ algo parecido ocurre para el arranque del 4.

s8 El impreso no tiene foliación, por lo que cito, sin hacer ninguna otra indicación, a partir del número de versículo.

59 KeITH WhINNOM, «El origen de las comparaciones religiosas del Siglo de Oro: Mendoza, Motesino y Román», Revista de Filología Española, XLVI (1963), pp. 268-291. 
peccatum meum grande / contra me est muy canino / semper pues que de contino / me ladra en el buen camino / y en malo haze que ande» (5). Las imágenes sacadas del Bestiario son, desde luego, las más frecuentes en la poesía religiosa medieval y muy usadas también por los predicadores. Más pintoresca resulta, sin embargo, la mención a una especie de Cristo antropófago, cuando el poeta trata sobre la preferencia divina de corazones contritos frente a sacrificios humanos: «No te deleytan comeres / de carnes sacrificadas / ni viandas muy guisadas / sino obras aprovadas / de los hombres y mugeres / no comes bravo coraje / ni muy limadas razones / ni delicado potaje / ni carne tierna salvaje / sino limpios coraçones». Y un poco después añade: «... assí que buena te sabe / el alma muy tribulada / no carne sacrificada / ni manida ni salada / que en tu estómago no cabe» (18). Mediante imágenes como estas los autores suelen poner en contacto la experiencia corriente de la vida diaria con el arcano religioso. Es otra muestra más del pensamiento analógico propio de la mente medieval, y paralelo a la interpretación tipológica de la Biblia.

Como puede comprobarse sin dificultad, los fragmentos más relevantes del poema corresponden a esas porciones totalmente ajenas a los versículos latinos. Ahora quisiera detenerme en una de esas cuñas amplificatorias que emplea un lenguaje en todo sentido paralelo a los códigos amorosos contemporáneos. Sucede en el abundamiento final a la paráfrasis del versículo 10: «So mis huessos mi saber / de mi carne so juzgado / humilde por no poder / de muy flaco sostener / mi desseo apassionado / vénceme la inclinación / ante quien la razón calla / y apenas oso mostralla / porque do fuerça se halla / vale poco la razón». Una contradicción entre la pasión y la razón, ahora en relación con el amor divino, que domina gran parte de las tribulaciones del amador cancioneril. En esta y otras coordenadas similares del lenguaje más puramente religioso se encierran las claves para la parodia en sentido erótico. En breve, iremos a ello. Lo mismo ocurre en estos salmos con el concepto de «servicio», tan recurrente como en el caso de Guillén de Segovia. Copio varios pasajes del $\mathbf{M i}$ serere, que pueden funcionar como ejemplo: «por poder te bien servir», 13; «mal servido y bien faltado», 4; «sino solo en tu servicio», 14.

Por lo que respecta al salmo 129, únicamente decir que está escrito en quintillas dobles, como el Miserere, pero comportando una ligera variación (abaabcdddc) con respecto a su esquema de rimas (abbbacdddc). Por lo demás, la técnica versionadora resulta igualmente amplificatoria, pero ahora se incrementa aun más si cabe, puesto que Luzón añade tres intervenciones del propio Jesucristo, pertenecientes a la completa invención del poeta. El título de la composición advierte de esta novedad desde el principio: Otra oración sobre el salmo "De profundis» por dialogo entre Nuestro Señor y el peccador. Como en los salmos penitenciales de Guillén de Segovia, tanto el De profundis 
como el Miserere van rematados con un gloria, donde el poeta toma la palabra para rogar el perdón por su ineptitud a la hora de recrear el verbo divino. En las dos ocasiones los términos son muy similares y aluden clarísimamente al tópico de la captatio benevolentiae. Dice en este salmo 129: «... perdon que con seso necio / queriendo dar buen sentido /en salmo tan escogido / puse mucho menosprecio». Y en el Miserere concluye de forma absolutamente paralela: «... mas perdon que he merecido / que peque con mi sentido / pobre simple entremetido / en salmo tan excelente».

Dando un salto temporal de casi cincuenta años, la paráfrasis de los Salmos en métrica endecasílaba, una profusa trayectoria que ya expuse en otra ocasión, principia a mediados del XVI con dos obras de Montemayor, la Devota exposición del psalmo miserere mei Deus, compuesta por veinte largas cánticas en endecasílabos sueltos ${ }^{60}$ y la versión del Super flumina, en tercetos encadenados ( «Sobre los ríos tristes nos sentamos...»), incluida en el Segundo cancionero spiritual (Amberes, 1558). Él mismo es autor de una recreación del salmo 86, todavía en octosílabos, la Exposición moral sobre el psalmo LXXX$V I$ del real propheta David (Alcalá Juan de Brócar, 1548) ${ }^{61}$, que contenía comentarios en prosa y verso. Los fragmentos líricos habían sido impresos con anterioridad al frente del libro de F. de Trasmiera, La Vida y excelencias de la Virgen (Valladolid, 1546) y fueron posteriormente editados - no sin retocar algunos versos y suplir los fragmentos en prosa no incluidos con nuevas estrofas- en 1554, en las Obras de devoción (Amberes, 1554) ${ }^{62}$. Pero en el espacio que media entre los salmos del portugués y los de Luzón pueden identificarse algunas continuaciones octosilábicas difundidas por medio del pliego suelto. En concreto, podrían aducirse, por ejemplo, Las siete palabras que dixo nuestro señor estando en la cruz trobadas. Con el Psalmo de Miserere mei (Toledo, 1525-1530) ${ }^{63}$ y las Coplas sobre los siete salmos penitenciales de David compuestos por un religioso, Salamanca, Juan de Junta, $1541^{64}$.

Estos resabios octosilábicos, casi a punto de publicarse las obras de Boscán y Garcilaso, merecen un comentario final. Aunque es cierto que después de la irrupción del endecasílabo siguieron existiendo algunas traducciones en arte menor, por ejemplo, el Super flumina de San Juan, la versión poética de los

o Cancionero, 1554, ed. cit., pp. 304-351.

61 FRANCISCO LOPEZ ESTRADA, «La Exposición moral sobre el salmo LXXXVI de Jorge de Montemayor», Revista de Bibliografia Nacional, V (1944), pp. 499-513.

${ }^{62}$ Ed. cit., pp. 122-131 («Hizo Dios una ciudad...»).

${ }_{63}$ ANTONio Rodriguez MoÑino, Nuevo diccionario bibliografico de pliegos sueltos (siglo XVI), ed. Arthur L. F. Askins y Víctor Infantes, Madrid, Castalia, 1997, n. ${ }^{\circ}$ 937, pp. 724-725.

${ }^{64}$ Ibid., n. ${ }^{\circ} 828$, pp. 656-657. 
Salmos, así como la del Cantar de los Cantares, se concibe comúnmente como el ejercicio de acomodación de unos textos, que al igual que los clásicos, puesto que con los autores grecolatinos se habían equiparado desde antiguo, requerían el cauce formal de la métrica italianizante ${ }^{65}$. Desde ese momento el acercamiento al modelo bíblico será de naturaleza muy distinta a la de los poetas de cancionero y estará guiado por un interés de apego a la fuente, no sólo en la métrica, sino también en la fidelidad al espíritu de la letra. Para los poetas humanistas los Salmos representan sobre todo odas bíblicas. Pero los parámetros para la adecuación no son de índole métrica en la poesía de cancionero ${ }^{66}$. $\mathrm{Pa}$ ra los autores cuatrocentistas la glosa sobre los cantos de David constituye una de posibles formulaciones del decir, con una dimensión marcadamente penitencial. Lo curioso es que ninguna de estas adaptaciones del Salterio se realice en el arte mayor castellano. Tal vez esto sea un indicio de que los Salmos son considerados, a pesar de todo, como poesía eminentemente lírica. A este propósito, recordemos la opinión de Díaz de Toledo ( «Dauid ... todo su Salterio escriuió en metro») o del mismo Santillana («Dauid cantó en metro... todos los cinco libros del Salterio») sobre la dimensión poética del libro sagrado.

\section{SALMOS DE AMOR PROFANO}

Para el poeta del siglo XV el lenguaje de la experiencia religiosa no sólo suponía un fin en sí mismo. También podía trascender los límites de la literalidad y describir los procesos amorosos que marcan su andadura poética. Esto no era una novedad, pero sí es cierto que durante las postrimerías de la Edad Media el fenómeno de la suplantación profana de los textos religiosos alcanzó unas cotas muy considerables. Sobre este hecho reparó Huizinga, para quien las razones de una lectura erótica de este tipo provenían de la absoluta familiaridad entre los contextos religiosos y profanos ${ }^{67}$. Pero al margen de una tendencia generalizada, la posibilidad de usar los códigos religiosos con otros fines surge de la adecuación conceptual entre el amor divino y la religión de amor practicada por el poeta de cancionero. Dentro de esa religio amoris, donde la divinidad es encarnada por la amada, o en otros casos por el dios Cupido, representación del amor,

${ }^{65}$ Lo he tratado, respectivamente, en mi «Versiones poéticas... y en Arias Montano y el Cantar, citados. Añádase, «De égloga a lo divino y bucólica sacra...».

6. Cfr. DE DIEGo, Los Salmos..., p. 26.

67 Johan Huizinga, El otoño de la Edad Media. Estudios sobre la forma de la vida y del espiritu durante los siglos XIV y XV en Francia y en los Patses Bajos, Madrid, Alianza, 1988, pp. 221 y ss., donde se refiere a elementos artísticos y a prácticas y costumbres cotidianas. 
en tanto que el papel de siervo siempre lo asume el amador anhelante, se despliega una serie de fenómenos poéticos que hacen gala de la síntesis erotico-religiosa ${ }^{68}$. A partir de esa analogía básica entre el amador y el cristiano resulta factible establecer la alegoría religiosa como código imaginístico de primer orden. El poeta compara incluso su sacrificio y pasión amorosas con la de Cristo y, a partir de ahí, comienza la asunción de toda una serie de términos provenientes del campo semántico religioso, que se transponen, con unas connotaciones más o menos eróticas, de modo absolutamente natural. Por doquier, nos topamos con vocablos como fe, siervo, sacrificio, mandamiento, gloria, pasión y otros muchos de la misma naturaleza ${ }^{69}$. Como sostiene Michael Gerli con razón, «Los poetas españoles del siglo XV, como sus antecesores italianos, escogieron la metáfora y la alusión religiosas... porque eran las formas que mejor expresaban la intensidad, el alcance y la complejidad de sus sentimientos eróticos» ${ }^{70}$.

Pero no sólo a la esfera de la terminología queda reducida la influencia de la secularización cuatrocentista. Abarca, asimismo, procedimientos poéticos de mayor alcance. Por ejemplo, María Rosa Lida llamó la atención sobre el uso de la hipérbole sagrada a la hora de encarecer a la amada, e incluso con vistas al halago de los poderosos ${ }^{71}$. Y también consignó en su trabajo otra faceta de esa esfera sacroprofana del cancionero: los poemas que citan o parodian los textos sagrados de la liturgia, plegarias, ritos, rezos o la Biblia ${ }^{72}$. En este caso, asistimos a un fenómeno de intertextualidad basado en la acomodación de citas religiosas, muchas veces en latín, o en la habilitación amorosa de modelos textuales sancionados por la tradición cristiana. $O$ sea, que contamos con dos propuestas para la recreación de textos sagrados, la incorporación de pasajes literales o bien la acomodación de distintos tipos de discursos religiosos. Un doble procedimiento que coexiste las más de las veces.

El origen para la amalgama de lo sacroprofano no resulta del todo clara. En realidad, conoce la misma indefinición que el propio concepto del amor cortés, puesto que constituye uno de sus principales integrantes. Pierre Le Gen-

68 Para este aspecto resulta imprescindible, MiCHAEL GerLI, «La religión de amor y el antifeminismo en las letras castellanas del siglo XV», Hispanic Review, 49, 1 (1981), pp. 65-86.

69 Sobre la ambivalencia del término pasión, uno de los más extendidos, ha tratado YvoNE TILlIER, «Pasión poetry in the Cancioneros», Bulletin of Hispanic Studies, 62 (1985), pp. 65-78. Ella misma es autora de una tesis doctoral sobre el tema: Religious Elements in Fifteenth-Century Spanish Cancioneros, University of Cambridge, 1985.

70 GerLI, art. cit., p. 68.

7 Téngase en cuenta para España, R. O. JONEs, «Isabel la Católica y el amor cortés», Revista de Literatura, XXI (1962), pp. 55-64. Pero el homenaje a los príncipes mediante metáforas religiosas es general en este período, según documenta Huizinga, ob. cit., pp. 223 y 270.

72 LIDA DE MALKIEL, «La hipérbole sagrada..... pp. 308-309. 
til vio un ascendente posible en la parodia goliardesca, cuyas blasfemias e irreverencias dejaron huella evidente en nuestro Libro de buen amor ${ }^{73}$. Las parodias, en efecto, fueron bastante numerosas en latín y en francés antiguo ${ }^{74}$. Pero existe una dificultad inicial para aceptar esta dependencia, ya que la parodia de los goliardos mantiene siempre un cariz satírico-burlesco, mientras que la imbricación erótico-divina de los cancioneros desconoce cualquier tipo de matiz risible ${ }^{75}$. Por ese mismo motivo, algunos críticos rechazan el término de parodia para este segundo elemento de alusión erótica de lo religioso ${ }^{76}$. Parte siempre de un planteamiento serio y, así, prefieren denominarlo contrafactum profano o secular ${ }^{77}$. Un término que permite relacionar el fenómeno con su cara complementaria: la divinización de textos amorosos previos ${ }^{78}$.

Dada la relevancia del Salterio en la vida religiosa del cristiano no extraña que el conjunto de los Salmos penitenciales constituya uno de los modelos más recurrente para la hibridación profana. Pero esa recreación de los cantos davídicos queda enmarcada por la parodia de una amplísima variedad de textos y prácticas sagradas. Hagamos un rápido recuento. Se contrahacen a lo humano diversas facetas de la vida devota: los rezos y letanías, como las de Valera; asimismo hay milagros, peregrinaciones y romerías del amor; martirios, penitencias, órdenes de amor ${ }^{79}$ y concilios (Torres Naharro, Concilio de los galanes y cortesanas de Roma, invocando por Cupido, Concilio venerense, 143-146). Se secularizan las horas canónicas (Nicolás Núñez, Cancionero General) y también los sermones ${ }^{80}$. Abunda la alegoría de infiernos (Sánchez de Badajoz Infierno de amor, «Caminando en las honduras»; Santillana) ${ }^{81}$ o purgatorios de amor (Bachiller Jiménez, Cancionero General) ${ }^{82}$. En cuanto a los textos litúrgicos, se

73 Se discute en GERLI, art. cit. p. 67. Ha de tenerse en cuenta, también, OTIS GREEN, «Courtly love in the Spanish Cancioneros», PMLA, LXIV (1949), pp. 247-301. Más concretamente sobre el Libro de buen amor, véase OTIS GreEN, «On Juan Ruiz's Parody of the Canonical Hours», Hispanic Review (1958), pp. 12-34.

${ }^{74}$ Para el ámbito francés, cfr. J. H. Marshall, «Pour l'étude des contrafacta dans la poésie des troubadours", Romania, 101, 3 (1980), pp. 289-335.

75 Félix LeCOY, Recherches sur le «Libro de buen amor», ed. A. Deyermond, Famborough, Griess International, 1974, pp. 214 ss., p. 216.

76 Por ejemplo, Gallagher, ed. cit.

77 Cfr. Casas Rigall, p. 186.

$78 \mathrm{Cfr}$. el libro clásico de Bruce W. WARDROPPER, Historia de la poesía lírica a lo divino en la cristiandad occidental, Madrid, Revista de Occidente, 1958. Asimismo, vid. John Crosbie, A lo divino Lyric Poetry: An Alternative View, University of Durham, 1989.

${ }^{79}$ GeRLI, art. cit., pp. 71-74.

80 LIDA DE MALKIEL, art. cit., p. 309.

81 Crosas, art cit., p. 104.

${ }^{82}$ Gerli, art. cit., p. 75. 
parodian los mandamientos de amor (Rodríguez del Padrón, Los mandamientos de amor ${ }^{83}$ ) o el padre nuestro (Luis de Salazar: Pater noster de las mugeres, Cancionero general; Rodrigo de Reinosa, «Un pater noster trobado a las damas»; Pater noster a lo humano, Cancionero antequerano). Muy curiosas y extendidas son las misas de amor, por ejemplo, la de Suero de Ribera ${ }^{84}$ y la de Juan de Dueñas ${ }^{85}$. La figura de la Virgen centra igualmente la atención de los poetas que secularizan algunos de los elementos con ella relacionados (Rodríguez del Padrón, Gozos de amor) ${ }^{86}$; y, por supuesto, menudean los poemas que parten de pasajes evangélicos o que toman como arranque palabras de Cristo o escenas de la Pasión ${ }^{87}$. Más en la esfera que nos interesa, sobre el Antiguo Testamento destacan las Liçiones de Job apropriadas a sus pasiones de amor, de Sánchez de Badajoz, y sus Lamentaciones de Jeremías ${ }^{88}$. En efecto, tanto Jeremías como Job guardan estrechas similitudes con los Salmos de súplica individual desde un punto de vista temático, por lo que muchos de los términos de comparación resultan ser los mismos en ambos.

Que este tipo de parodia amorosa fuera tan abundante en los cancioneros del XV no es óbice para que no existiera en paralelo una denuncia de su talante heterodoxo. Y no sólo los moralistas reaccionaron adversamente sobre la síntesis sacroprofana, incluso los propios poetas fueron conscientes de que relegaban el papel de Dios, encumbrando a las amadas a un blasfemo primer plano, como Donna angelicata. Así se refiere Íñigo de Mendoza a ese sacrílego servicio de amor: «razón es de reprochar / el continuo ydolatrar / de nuestros falsos cristianos» ${ }^{89}$. Michael Gerli ha explicado, precisamente, la aparición del intenso espíritu misógino del XV como una reacción contra esa suerte de idolatría. Un testimonio especialmente interesante sobre las consecuencias morales de la versión secular de lo religioso pertenece al anónimo autor de El libro de la celestial jerarquía (s. l., s. a., 1511?). En él achaca la locura en que quedó sumido Sánchez de Badajoz a la versión profana que hizo del Job. Un parecer que repite más tarde Luis Zapata en su Miscelánea:

${ }^{83}$ Cfr. Juan Rodriguez del. Padrón, Obras completas, ed. César Hemández Alonso, Madrid, Editora Nacional, 1982, pp. 320-328. También. M. S. Gilderman, "The Profet and the Law: Some observations on Rodríguez del Padrón Diez mandamientos de amor», Revista de Estudios Hispánicos, VII, 3 (1979), pp. 417-426.

84 Gerli, ed. cit., p. 118.

85 J. Piccus, «La misa de amores de Juan de Dueñas» NRFH, 14 (1960), pp. 322-325 y A. AlatorRe, «Algunas notas sobre la misa de amores, ibid., pp. 325-328.

${ }^{86}$ Ed. cit., pp. 309-319. Asimismo, M. S. GildermanN, «Toward a revaluation of Rodríguez del Padrón and his poem of coutly love 'Siete gozos de Amor'», Hispania, 56 (1973), pp. 130-133.

${ }^{87}$ Crosas, art. cit., p. 79.

88 Hay otras lamentaciones de TORRES NAHARRO. 
... las cosas de la Sagrada Scriptura profanava trayendolas a su vano amor, o mas verdaderamente furioso desatino, como paresce en las Liciones de Job por el trobadas; las quales quando me fueron mostradas no pude sino maravillarme porque después de la elegancia de palabras estavan alli cosas tan primas del amor divinal que no pude yo sino dezir que todo pecado, en especial este vano desatino es idolatria ${ }^{90}$.

Y lo cierto es que la composición pasó a engrosar la lista de obras prohibidas en el Índice de Valdés. De cualquier modo, el clima circundante parece adoptar, en general, cierta permisividad con respecto a las correspondencias entre lo sacro y lo secular, y todo debido a la práctica extendidísima de tales trasvases. Algo que sucede, por supuesto, hasta bien entrado el siglo XVI. En 1567, por ejemplo, Martín de Azpilcueta, hablaba en su Manual de confesores y penitentes, de la mezcla de los «cantos seglares» con el «culto divino», maridaje que, según él, se acostumbraba muy comúnmente. Y mantenía que: «no parece pecado mortal sino quando la canción es torpe y suzia, o vana o prophana, cantada durante el oficio diuino" ${ }^{91}$.

Así pues, en sintonía con este fenómeno secularizador, la pauta del amor humano se impuso varias veces sobre el esquema penitencial del Salterio, dando lugar a contrafacturas eróticas de bastante homogéneo significado. Casi rondando la mitad del XVI, en 1542, Cristóbal de Castillejo en el Sermón de amores, donde precisamente él mismo cita diversos fragmentos latinos con afán paródico, alude, en un momento dado, al uso de los Salmos con fines eróticos. Le pregunta el poeta al Amor: «¿Quién te trajo al monesterio, / amor poderoso, di, / que muchas veces por ti / mientan versos del Psalterio, / que es donaire?» (vv. 631-636) ${ }^{92}$. Y unos versos más abajo aplica el libro divino como comparación, en un contexto absolutamente obsceno. El «pecador» de amor no consigue seducir a la amada, pero se conforma con sus excusas: «Ya el cuitado / de lo dicho confiado / como si fuese el Psalterio, / piensa que va algún misterio / y que todo va fundado / sobre cierto" (vv. 961-965) ${ }^{93}$. Tales fragmentos muestran muy claramente la costumbre tan extendida de utilizar los Salmos davídicos con un significado procedente de contextos amatorios. Una práctica

99 Apud GerLI, art. cit., p. 80.

90 Apud Gallagher, ed. cit., pp. 39-40.

91 Manual de confesores y penitentes, pp. 117-118. Apud Keith Whinnom, La poesia amatoria de la época de los Reyes Católicos, Durham, University of Durham, 1981, p. 22.

92 Cristóbal de Castillejo, Obra completa, ed. Rogelio Reyes Cano, Madrid, Tumer, 1998, p. 196.

${ }^{93}$ Ibid., p. 204. Y repárese en que cita a RodRÍGUEZ DEL PADRÓN y sus Siete gozos de amor en el v. 2531. 
que antes de doblar el siglo parece ser aún factible. Por ejemplo, en el Tratado notable de amor de Juan de Cardona (1545-1547), una novela donde de modo progresivo se van incorporando referencias sacrílegas, la protagonista, Ysiana, recrimina la actitud de su enamorado en los términos siguientes: «Sabés, Cristerno, que me parece de estos atrevimientos conmigo como a Dabid con Dios, que no hazía sino herrarle y pasar sus mandamientos, y después, con sollozar y dezir 'pequé' cada ora le perdonava, y así bos azéis lo mismo" ${ }^{94}$. No cabe ninguna duda sobre la reiterada igualación entre el amador y el salmista.

$Y$ es que la figura misma de David llega a entrañar en su propio comportamiento humano, y frente a Dios, la doble dimensión amorosa y divina. Su actuación se interpreta como una muestra extrema del poder del dios Amor sobre los hombres, incluso en el caso de un comportamiento tan recto y virtuoso como el suyo. Así se constata, por ejemplo, en otra muestra mucho más temprana de la ficción sentimental, lo cual incide en la amplitud del motivo, la novela de Luis de Lucena titulada Repetición de amores (Salamanca, 1495). En ella el autor refiere una larguísima casuística de amadores, entre los que se cuentan muchos hombres señalados y de gran dignidad. Comenta Lucena:

Verás aquel santo varón David, cómo fue por amor vencido quando se enamoró de Bersabé, que... por la haver libremente a su querer, fue consentidor en la muerte de Urías, su marido. Gran auctoridad es ésta para haver conoscimiento de la potencia que este dios Cupido tiene sobre todos los hombres, que, como David fue en todo el linage humanal escogido por justedad e aun sabiduría por la gracia divinal a él dada, que así paresce por lo que dixo en el salmo: «El secreto de la sabiduría me diste a entender». E así se apoderó en él el amor que, no solamente le hizo negar su buena e casta condición, mas hízole offender a su criador, a quien el siempre tuvo gran reverencia ${ }^{95}$...

Tampoco quisiera dejar de llamar la atención sobre otra posibilidad en la paráfrasis de los Salmos, que entraña igualmente una secularización del texto bíblico, si bien no con miras amorosas, sino con afanes políticos. No es un hecho aislado. Debemos recordar la serie de elogios por parte de Antón de Montoro, Tapia o Cartagena destinados a la reina Isabel, y que toman como base la hipérbole sagrada. En realidad, no he podido documentar ningún ejemplo

94 JUAN DE CARDona, Tratado notable de amor, ed. Juan Fernández Jiménez, Madrid, Ediciones Alcalá, 1982, pp. 124-125.

5 Tomo el texto de la edición de Miguel M. BERMEjo en Tratados de amor en el entorno de Celestina (Siglos XV-XVI), ed. Pedro M. Cátedra, Madrid, Sociedad Estatal España Nuevo Milenio, 2001 , p. 110. 
de salmos de circunstancias en la poesía de cancionero, pero me parece que puede ser interesante recoger varias muestras posteriores, para comprobar el grado de familiaridad con que se acoge el modelo de los Salmos en los más variados eventos. La muestra más antigua, en lo que se me alcanza (1517), es un Psalmo de Bartolomé de Torres Naharro en la gloriosa victoria que los españoles ovieron contra venecianos ${ }^{96}$; en una época más o menos contemporánea, Pedro Manuel de Urrea, incluyó en su cancionero un Ave María de los franceses glosado contra los actos de Francisco I. De tipo reivindicativo es también El psalmo Super flumina Babbylonis aplicado a la vida que se passaua en Ynglaterra, estando en ella el Rey Don Felipe con su corte. Año de 1555, publicado en el Cancionero General de Amberes, $1557^{97}$. Esta vez con miras de encarecimiento áulico, Miguel Ferrer, en un pliego suelto de 1571, plasmó el Laudate dominus para conmemorar la victoria de don Juan de Austria en Lepanto ${ }^{98}$.

Pero volvamos al ámbito amoroso, que es el que verdaderamente nos interesa. De entre todas las recreaciones seculares sobre los Salmos, la de mayor envergadura, porque contrahace el conjunto de los siete penitenciales, es la que llevó a cabo Diego de Valera ${ }^{99}$. En este sentido se puede parangonar con la obra religiosa de Guillén de Segovia. Téngase en cuenta, además, que ambas se copian en el Ms. 2763 de la Biblioteca Universitaria de Salamanca ${ }^{100}$. Es cierto que existen entre ellas muchas diferencias, pero a la vez se aprecian algunas similitudes. En primer lugar, destaca la regularidad dispositiva del poema, cada una de cuyas partes está conformada por ocho coplas (abbbaaccca), más un gloria que se repite en cada uno de los salmos, a modo de estribillo: «a ti señor soberano / den gloria todas las gentes / pues señores e servientes / goviemas por la tu mano» (I-VII, vv. 50-53) ${ }^{101}$. Ese remate afianza todavía más si cabe el sesgo paródico, pues constituye un práctica común en el rezo cristiano, y así lo comprobamos en las dos versiones de Luzón. A Diego de Varela no le interesa en este punto un seguimiento absolutamente análogo del modelo bíblico, pero el paralelismo con el Salterio resulta considerable, a pesar de

96 Bartolomé de Torres Naharro, Obra completa, ed. Miguel Ángel Pérez Priego, Madrid, Turner, 1994, pp. 133-139.

97 ANTONIO Rodríguez MoÑino, Suplemento al Cancionero General, Valencia, Castalia, 1959, n. 304 , p. 261.

98 ANTONIO RODRIGUez MoÑino, Pliegos poéticos de la colección del marqués de Morbecq (siglo XVI), Madrid, Estudios bibliograficos, 1962, pp. 259-265.

99 Salvador Miguel, ob cit., pp. 242-255.

100 Tomo el texto de Brian Dutron, El Cancionero del siglo XV c. 1360-1520, Salamanca, Universidad, 1991, IV, pp. 197-200. Citaré por el número de salmo y verso.

101 Imagen correlativa con la que aparece en Guillén y que ya se ha comentado. 
no introducir ningún elemento latino. En esto se parece también a los salmos de Guillén, frente a otras recreaciones en seso, lo cual podría ser un síntoma de la asimilación directa de la obra.

Los salmos van «dirigidos al amor», según reza el título, clave de interpretación profana extensible para todo el poema. Efectivamente, en estos y otros salmos amorosos la situación del enamorado o pecador y su petición de perdón hacia Cupido ${ }^{102}$ se manifiesta de un modo tipificado. Como corresponde al Dios padre del Antiguo Testamento, Amor se dibuja como un juez sañudo («tu saña muy espantable», III, 29) y airado. Y eso es lo que le ruega el pecador, que se apiade de él y que no lo castigue con su furor. Esa penitencia que le inflige de continuo la interpreta el amador como un agravio comparativo. Supone una situación del todo injusta, puesto que él siempre le ha sido leal. Su acatamiento consiste, y en ello incide una y otra vez, en prestarle servicio sin ningún tipo de engaño. Él solicita un «galardón», por haber servido a una sola dama, como corresponde a la convención cortés: "pues errando sola una / vien siruiendo te enoje / aquesta sola serui / no pensando que te errava» (IV, 23-26). Sería el premio justo para sus «cuitas» y «cautiverio» actuales. En cuanto a la revisión de la vida pasada, el amador se identifica plenamente con el salmista, puesto que ejerce una palinodia desde la vejez y la enfermedad, siendo consciente de los errores cometidos:

pues confieso mis errores
merezco ser perdonado
y de ti galardon dado
pues amé bien por amores
o señor de los señores
en tu gloria cantaré
i en todo tienpo daré
a tu santidad loores
mis huesos envejecidos
vien amando te rreclaman
e sospirando te llaman
dando vozes y gemidos
no te plaga que perdidos
sean los que confesaron
los yerros en que toparon
con dolores aflegidos (II, 2540).

102 Para la imaginería del dios Cupido en el XV, cfr. Francisco Crosas LóPEZ, La materia clásica en la poesía de Cancionero, Kassel, Reichenberger, 1995, pp. 40-46. 
Quienes han causado su envejecimiento son precisamente las cuitas que lleva padeciendo desde la juventud: «Quen mi juventud ferido / fui de tu flecha plomada / e mi persona llagada» (III, 9-11). Ese tormento constante proviene del permanente deseo, nunca satisfecho, del «amador no bien amado»: «rremedia señor siquiera / por mi cuyta rreparar / quel continuo desear / perturva toda carrera / de vienes a quien espera / sus males nunca çesando» (V, 33-38).

Dos características comparten estos salmos de Valera con otros textos paródicos similares. Por un lado, la identificación de Venus, madre de Cupido, como la Virgen María («Miserere mey cupido / fijo de la madre santa / cuya gloria sienpre canta / el tu pueblo fauorido», IV, 1-4) y, por otra parte, la mención de Macías en calidad de santo o profeta del amor: «que solo por yo seguir / la doctrina de maçias / bien como sombra mis dias / pasaron sin rreçebir / galardon ante sofrir» (V, 9-13). Justamente, a los salmos penitenciales le sigue en el citado manuscrito salmantino una famosa Ledanía ${ }^{103}$, en la que Valera se encomienda a amadores como Orfeo, Píramo, Sesto, también en calidad de Santos, para que intercedan por su cuita de amor. Entre ellos no se cuenta Macías, pero en otras composiciones análogas aparece como prototipo del mártir amoroso.

Me interesa, por último, llamar la atención sobre la autodefinición poética que hace Valera de su propia composición, nombrándola como decir («plega te señor oyr / mys devotas oraçiones / e mys rrudas conclusyones / en este breve dezir», VII, 1-4) e insistiendo en su realización en tanto texto leído, y por ello, plasmado mediante la escritura («en el punto que estos leo», VI, 30). Asimismo, realiza otra referencia metapoética acerca de la entidad blasfematoria del contrafactum que merece la pena reseñar: «que munchas vezes fablando / de tu merçed blasfemamos / con la vida que pasamos / nuestras cuytas rremenbrando / y tanvien señor callando / el tu nonbre maltratamos con la pena quesperamos / de ti muncho nos quexando» (VII, 17-24).

En el Miserere de mosén Francisco de Villalpando ${ }^{104}$, que se documenta en el Cancionero de Palacio, donde fue tachado por una mano censuradora, se aprecia aun mejor si cabe cómo la confesión del pecador arrepentido ha sido provocada por la actuación paradójica del «dios d'Amor». Le increpa, por tanto, con enfado: «Muestra tu poder tamanyo / y déveslo destruyr / a quien ama con enganyo / y muchas quiere servir; mas el que te sierve bien / no lo quieras perseguir, / senyor, antes lo sostiene» $(85-91)^{105}$. Desde un punto de vista mé-

${ }^{103}$ DutTon, ob. cit., p. 200.

104 Sobre su hermano Juan y él mismo, cfr. Salvador Miguel, ob. cit., pp. 258-260.

105 Cancionero de Palacio, ed. Ana M. Álvarez Pellitero, Salamanca, Junta de castilla y Le6n, 1993. pp. 78-83. 
trico, esta versión consta de 136 versos distribuidos en estrofas mixtas, formadas por una redondilla y un terceto $(a b b a c b c)$, de los cuales los tres últimos constituyen un fin recapitulador: «Este salmo contemplando / mi fortuna pasaré / de ti mercet esperando» (135-137). El autor no llega a intercalar los términos latinos de la Vulgata, pero sí va desgranado los versículos correspondientes al frente de cada estrofa. No voy a insistir mucho en lo que ya he dicho con respecto a los salmos de Varela. El paralelismo temático es casi total, pero aquí se pone más de relieve la actuación sin sentido del Amor. Por eso, mejor que ante un arrepentimiento podríamos asegurar que nos encontramos frente a una rebelión en toda regla contra él. Las cotas máximas de descontento por la injusticia del dios se expresan en la glosa del Tibi soli pecabi: «A ti solo no pequé / amador siendo leal, / pues, Amor, dime por qué/ me das pena desigual; /justifícate, senyor, / siempre no seas tal / contra mí tu servidor» (22-28). Tampoco le van a la zaga los versos del Benigne fac Domine: «Sed benigno e piadoso / a quien ama lealmente, / y también sey orgulloso / al de falso continente; / e no fagas al revés, / que, senyor, a buen servir, / como sueles, pena des» (120-126). En definitiva, Villalpando, como los otros poetas anteriores, se hace eco, tomando como base la adaptación de los Salmos, de uno de los temas recurrentes de la poesía de cancionero: las quejas por el proceder caprichoso del dios Amor, en paralelo a las veleidades de la Muerte, la Fortuna y de la propia dama ${ }^{106}$.

Conjuntamente con los salmos de Guillén de Segovia, en el Cancionero General de 1511 tuvieron cabida las coplas (abaabbcbbc) de Mossén Gaçull, Aplicando el salmo De profundis [129] a sus passiones de amor. Como hiciera Luzón en sus dos paráfrasis correspondientes, este poeta incluye frases de la Vulgata, con las cuales va marcado la estructura de la composición. Al principio de cada semiestrofa aparecen uno o dos términos latinos ${ }^{107}$. Aunque el tono sigue siendo parecidísimo al de los dos ejemplos precedentes, en este caso Gaçull introduce una significativa variante. Se dirige, no al dios del Amor, sino a la propia dama esquiva, representación clarísima de la belle dame sans merçi («Quia apud mis grandes daños / está firme tu crueza», 163, $2{ }^{108}$ ), a la que idolatra como a Dios mismo: «De profundis he llamado / rogando a su señoría, / pues me tienes olvidado, / que me buelvas al estado / que primero ser

106 Cfr. Rodado RuIz, ob cit., pp. 144-145.

107 Sobre la interpretación erótica de los latines incrustados en poemas cancioneriles, véase DONALD MCGRADY, «Macaronic latin and religious parody in Soria's Transeat a me calix iste», Bulletin of Hispanic Studies, 75 (1998), pp. 265-271.

108 Cancionero General de Hernando del Castillo, Madrid, Bibliofilos Españoles, 1882, I, pp. 163-164. Cito por la página y columna. 
solia» $(163,1)$. Todos los males de amor se deben a la belleza de la dama, que, sin embargo, no ofrece galardón a sus servicios. El amador enfermo solicita que le remedie su mal con «favores» y que reconozca su equivocado comportamiento: «Ex omnibus penas mias / presto libre me verás, / si conosces que deuias / no darme tan malos dias, / sin culpable ser jamás» $(164,2)$. Probablemente sea ésta la versión profana que incorpora los eufemismos más marcadamente eróticos ${ }^{109}$. Desde luego, el salmo debió de ser bastante conocido por su osadía paródica. Y así, Félix Lecoy señala cómo Mario Equicola, para apoyar su reprehensión de este tipo de práctica, en su Libro di natura d'Amore (1525) menciona un $D e$ profundis paródico, que no debe ser otro que el poema de Gaçull ${ }^{110}$.

Con estos tres autores, no acaba, sin embargo, la recreación del Salterio en el ámbito del cancionero. Junto con las glosas de los Salmos penitenciales, ya aislados, o bien en su conjunto, también se parafrasean a lo profano otros salmos fuera de este corpus, que generalmente se integran en una composición de mayor alcance. Es decir, en estos casos, la parodia de los Salmos suele ser más fragmentaria, porque se espigan sólo ciertos versículos, y siempre depende de un contexto sagrado más amplio. Por ejemplo, en el ritual de la misa y, paralelamente, en la parodia correspondiente de la misa de amor, se inicia la liturgia con la paráfrasis del Iudica me, Deus, (salmo 25), una oración donde el pecador enuncia su descontento vital, lo mismo que en los Salmos penitenciales. Tanto en el poema de Dueñas como en el conocidísimo de Suero de Ribera, a los que antes me referí de pasada, aparece algún rasgo todavía destacable, por más que la unidad de sentido sea enorme con respecto a los salmos ya comentados. En la misa de Suero de Ribera, cuyo texto, como ocurriera con Villalpando, fue tachado en el Cancionero de Palacio y arrancado en otras compilaciones, el poeta recomienda al Amor que haga un juicio formal para discernir los leales amadores de aquellos otros que no lo son: «Pues de buena voluntad / te loamos los amantes / no quieras ser como antes / eras con gran crueldad; / mas faz corte general, / perdonando todos males. / Por tu merced non iguales / el discreto conversante / con el simple inorante, / pues que non es igualdad, / sino muy desconcordante" ${ }^{111}$. La dimensión jurídica, en efecto, tan importante en la formación del caballero medieval, sirve de base para los reproches dirigidos al Amor en algunos poemas del cancionero, por ejemplo en

109 Teniendo en cuenta la pauta interpretativa de KerTH WhINNOM en trabajos como «Hacia una interpretación y apreciación de las canciones del Cancionero General de 1511», Filología, XIII (1968-69), pp. 369-381 y La poesía amatoria de la Época de los Reyes Católicos...

110 F. LECOY, ob. cit., p. 222.

111 Poesía de cancionero, ed. Álvaro Alonso, Madrid, Cátedra, 1991, pp. 192-193. 
el debate de Jorge Manrique «quexándose del dios de amor y cómo razonaban el uno con el otro" ${ }^{112}$. Diversos procedimientos jurídicos dan pie, en este sentido, a alegorías amorosas como el Pleito de amor de Alfonso Vidal, la Ley de amor de Suero de Ribera o una nutrida colección de testamentos amorosos ${ }^{113}$.

Por su parte, en la Misa de amores de Juan de Dueñas se establece una especie de santoral erótico, compuesto por Tristán, Lanzarote y otros amadores afines, entre los que se incluye, por supuesto, el enamorado Macías ( Lectio libri del saber: / Amor en aquellos día, / segund que puso Maçías / lo deuen todos creer», copla $17^{114}$ ), una lista que comienza nada menos que por la alusión a una Santísima Trinidad pagana. A esta guisa corresponde el blasfemo gloria de la composición, uno de los textos más irrespetuosos de todo el corpus paródico: «Gloria patri, linpio manto / de amores, el qual cobijo / válgame con el tu fijo. / graçia del espíritu santo; / Cupido, Venus y Apolo, / tres personas y un dios solo: / esto creo y mas de tanto» (copla 7).

A pesar de la intensidad sacrílega del texto precedente, que no se detiene siquiera ante el misterio de la santísima Trinidad, la cota más elevada de blasfemia en toda la serie de salmos a lo profano se produce, a lo que creo, en la versión paródica que Juan del Encina incorpora en un ámbito próximo a la poesía de cancionero, su Égloga de Plácida y Victoriano (vv. 1547-2186). En primer lugar, por el contexto temático que la rodea, ya de por sí altamente pecaminoso, auque muy frecuente, por ejemplo en la resolución temática de la ficción sentimental. Porque tras el suicidio de Plácida, la protagonista despechada, su amado Vitoriano reza una Vigilia de la enamorada muerta ${ }^{115}$, donde reelabora de modo profano el oficio de difuntos. Podríamos hablar aquí de un contrafactum extremo ${ }^{116}$. La paráfrasis amatoria consta de tres partes, siguiendo el esquema de la liturgia funeral, las dos primeras de las cuales tienen como referencia diversos Salmos relacionados con el rezo específico. La tercera, por su parte, consiste en el contrafactum de tres de las Lecciones de Job leídas en el oficio litúrgico, que, como ha visto la crítica, guardan estrechas

112 Jorge Manrique, Poesía, ed. Vicente Beltrán, Barcelona, Crítica, 2000, pp. 98-104.

113 Casas Rigall, ob cit., pp. 84-85.

114 Piccus, art. cit., pp. 323.325.

115 Existen dos trabajos específicos sobre el pasaje: A. HANSEN, «Adaptaciones del oficio de difuntos a lo humano: Job en las quejas amorosas de Garci Sánchez de Badajoz y Juan del Encina», Ibero-romania, X (1979), pp. 47-62; GUIDO MANCINI, «Una veglia funebre profana: la Vigilia de la enamorada muerta di Juan del Encina», Studi dell Istituto Linguistico (Universitd di Firenze), 14 (1981), pp. 187-202.

116 Así lo denomina Alberto del Río, ed., JuAN DEL ENCINA, Teatro, Barcelona, Crítica, 2001, p. 359. Cito el texto por esta edición (pp. 227-240) y me sirvo, asimismo, de sus notas explicativas. Téngase muy en cuenta, además, la ed. de Miguel Ángel Pérez Priego, Madrid, Cátedra, 1991. 
concomitancias con el texto de Sánchez de Badajoz ${ }^{117}$. Las palabras de Victoriano principian con un Invitatorium constituido por un villancico glosado, cuyo estribillo reproduce fragmentos del salmo 114, 3: «Dolores de amor y fe / ¡ay, circumdederunt me!» (1549-1550). A su vez, cada una de las estrofas incorpora en el primer verso términos latinos de algunos versículos del salmo 94 . Éstos le sirven al poeta como punto de partida para verter sus propias consideraciones, siempre de modo muy alejado del sentido primigenio.

En verdad, la paráfrasis de los Salmos que lleva a cabo Juan del Encina es absolutamente libre, la más divergente con respecto a la Vulgata de cuantas he analizado. Dos ideas resaltan en este inicio. Por un lado, el firme propósito de suicidarse que acaricia el protagonista, como único medio para reunirse con la amada (dice: «porque mi muerte veréis», 1555) y por otro, el injusto proceder del dios Cupido. Y esto último convierte su plegaria en un auténtico denuesto o quejas contra el Amor, un género que proliferó en la poesía de cancionero, especialmente en poemas de debate como los de Manrique, Garci Sánchez, Cartagena, Rodrigo Cota, Tapia o el propio Juan del Encina. Por eso, insta a todos los amadores a que renieguen de su culto: «Hodie, los que me oís, / huid de seguir su vía» (1572-1573). Pero, a pesar de rechazarlo él mismo, paradójicamente, se le encomienda en oración como forma desesperada de conseguir su propósito, que no es otro que la muerte liberadora. Sólo esta última estrofa del Invitatorium no mantiene el estribillo consiguiente, ni refiere ningún término del Salmo: «Dirige, señor, dios mío / dios Cupido, dios de amores, / dios en cuyo mal confío, / los sopiros que te embío, / mis vías con tus clamores / porque vaya / donde es por fuerça que caya / de un error en mill errores» (15861593). Se trata, en efecto, de una transición entre el segmento inicial, al que se une temáticamente, y la sección siguiente, con la que guarda la misma estructura métrica (8a-8b-8a-8a-8b-4c-8c-8b) ${ }^{118}$.

Esta parte segunda consta de tres salmos, el quinto, sexto ${ }^{119}$ y séptimo de la Vulgata, correspondientes al primer nocturno de maitines. Cada uno de ellos finaliza con la consabida antífona (requiem aeternam), propia del oficio de difuntos ${ }^{120}$. No son regulares ni en su extensión (15-10-18 estrofas), ni siquiera en el espacio dedicado a las respectivas antífonas. De nuevo, la desproporcionalidad, como en otros casos examinados, obedece a la técnica glosadora, con-

117 El primero en referirlo fue ANTONY VAN BEYSTER VELDT, La poesía amatoria del siglo XV y el teatro profano de Juan del Encina, Madrid, Ínsula, 1972, pp. 281-282. Cfr. HANSEN, art. cit.

118 Ya comenté que las estructuras con un pie quebrado eran frecuentes para el canto fúnebre.

119 Recuérdese el primero de los penitenciales.

120 Segunda, tercera y cuarta antífonas del primer nocturno de maitines. 
sistente en incluir los incipit de cada versículo del Salmo en el primer verso de las estrofas ${ }^{121}$. Lo que ocurre en este caso, tal como comentaba con anterioridad, es que el seguimiento del sentido del texto bíblico se esfuma casi por completo. Es más, prácticamente se podría afirmar que la paráfrasis profana de Juan del Encina contraviene las sentencias de la Escritura. Los Salmos 5, 6 y 7 son oraciones de un pecador justo y enfermo, calumniado por enemigos impíos, que pide a Dios la liberación de tales hostilidades para que lo conduzca a la salud del alma. Sin embargo, la acomodación a que los somete el poeta resulta francamente distinta. Y esa divergente adecuación se debe, sin duda, a la desesperanza que lo tiene embargado y resuelto a quitarse la vida. Por eso constata, «no tengo defendimientos» (1598) y, lo que es más grave aún, adolece de cualquier atisbo de fe en su salvación futura: «sin ninguna redempción. / Yo, perdido, / no espero ser redemido / de tan grande perdición» (1630-1633). Idea que reitera en el requiem conclusivo: «Por amores, / siempre crezcan mis dolores / sin ninguna redempción» (1719-1721). Es consciente, así pues, de que su proyectado suicidio lo sumirá en el infierno junto con la amada: «Convertere, dios Cupido, / saca mi alma del mundo, / esto te ruego y te pido. / No lo pongas en olvido. / Da con ella en el profundo, / con aquesta / que robaste agora désta, / sea yo luego el segundo» (1722-1729). Victoriano, en definitiva, hace culpable de todos sus pesares al Amor, al que considera un dios injusto: «a ti demando favor / y tú nunca me lo das» (1613-1614).

Con el salmo siguiente, recreación del primero de los penitenciales, la rebeldía del personaje adquiere una línea ascendente de acritud que le conduce al trastrueque premeditado del contenido bíblico. Frente al ruego del salmista («No me castigues en tu ira, no me aflijas en tu indignación») las palabras de Victoriano no pueden ser más elocuentes: «Domine in furore tuo, / ruégote que me condenes...» (1730...). Y en esta tesitura el miserere deus se transforma en "Miserere mei, Amor, / desesperan mis cuydados. / Sea mi pena y dolor / la más grave y la mayor / de los más atormentados» (1738-1742); y el libera anima mea pasa a ser un resolutivo «libra mi alma de gloria» (1755). Incluso esos enemigos de los que el salmista pretende zafarse quedan conculcados para hacer más rápido el desenlace fatal: «Vengan todos los dolores / en la muerte acompañarme. / Todos quantos / oyen la voz de mis llantos / den favor para matarme» (1789-1793). Y como aldabonazo final, se cierne el firme propósito del suicidio: «que yo me mataré luego. / No hay ninguna redempción» (1797-1798).

La clave para lo que se desarrollará en el último de los salmos la adelanta Victoriano poco antes de la antífona del segundo: «soy contento pade-

121 Salvo para 5, 11, donde se emplean dos estrofas 
cer» (1806) ${ }^{122}$. Ahora se llega a un clímax temático por medio del cual el personaje detalla las penitencias y suplicios que le implora al dios del amor, con muchísima insistencia: «venga la furia y muy fuerte, / la más orrible y escura, / que es mejor, / para acabar mi dolor» (1829-1832); y lo recalca con la idea de que no admita duda posible: «yo quiero ser muy punido» (1836), «yo quiero sofrir la pena» (1843). Victoriano exige un tormento ejemplar, infligido con las flechas mortíferas de su dios justiciero: «Exurge, domine, in ira, / y ensalça tu presunción; / con tu saetas me tira, / y encara y assesta y mira / que des en el coraçón, / con dolores / tan grandes, que a los amores / tornes en desesperación» (1858-1865). Con este regodeo en la tortura física, el personaje alcanza la entidad de un mártir sacrílego. No obstante, y a pesar de todo, finaliza su plegaria blasfema exculpando su proceder y el de su amada Plácida: «pues que ya sabes que nos / no pecamos por malicia / ni maldad, / mas por una liviandad / de enamorada codicia» (1956-1961). No existe premeditación, sino únicamente pasión mutua y enfermiza.

Esta paráfrasis extrema de Encina y todas las reformulaciones profanas del salmista tienen su razón de ser en una identidad subyacente. Es decir, el poeta de cancionero encuentra en la súplica ante el Dios del Antiguo Testamento unos códigos e imágenes que puede hacer suyos sin mucha dificultad. Existe una sintonía entre el carácter penitencial de los Salmos y la actitud y suplicios del amador arrepentido y condenado al cautiverio de amor. El poeta puede canalizar, de este modo, y con óptimos resultados, el tópico cortés de la penitencia de amores. Así pues, sin esfuerzo aparente y con la mayor naturalidad, resulta factible acomodar los versículos bíblicos a los afectos amorosos. En realidad, en los Salmos penitenciales, la búsqueda de Dios coincide en los medios con el recorrido amoroso, a pesar de que su fin sea, desde luego, diferente: en el contexto religioso se anhela la salvación del alma y en el ámbito erótico la salud del cuerpo. Con una imbricación tan armonizada no es difícil identificar aquí y allá alusiones que, si bien, no dependen premeditadamente del lenguaje de los Salmos, recuerdan poderosamente el clima suplicante que les es propio. En el Cancionero de Palacio leemos, por ejemplo, una composición de Martín Tañedor que puede servir como muestra perfecta de las concomitancias de este tipo. Aunque no glosa ningún salmo en concreto comparte lugares paralelos con varios pasajes del Salterio $(10,1 ; 83,1)$. En esta canción amorosa, en definitiva, el lenguaje del amor se hace absolutamente compatible con el discurso religioso, sin la necesidad de una táctica versionadora de orden

122 Un mote de Soria resulta casi idéntico («contento con padescer») y cifra toda la entidad paradojica del amor de cancionero. Cfr. Álvaro Alonso, ed. cit., n. ${ }^{\circ} 129$, p. 369. 
explícito. La pauta para la adecuación proviene de la naturaleza divina de la amada, a quien el poeta le habla como a su Dios, suplantándolo. Tal vez en ese paralelismo conceptual se cifre el éxito de los Salmos penitenciales de amor profano:
Ay, señora, por tu fe
no me tengas apartado
de tu gracia et merçe
pues veyes que mi querer
es todo tu mandar
no me quieras olvidar
que tuyo so et sere, si no siempre cridare
no me tengas apartado
de tu graçia et merçe ${ }^{123}$.

${ }^{123}$ Apud GerLI, art.. cit., p. 72. 